\title{
Correlation of Electric Conductivity Values with the Dairy Milk Quality
}

\author{
Yanthi ND ${ }^{1,2}$, Said $S^{2}$, Anggraeni $A^{3}$, Damayanti R ${ }^{4}$, Muladno 5 \\ ${ }^{I}$ Postgraduate student of Production Science and Livestock Technology, Bogor Agricultural University \\ ${ }^{2}$ Biotechnology Research Center, IIS, Cibinong, Bogor \\ ${ }_{3}^{3}$ Indonesian Research Institute for Animal Production, P.O. Box 221 Bogor 16002 Indonesia \\ ${ }^{4}$ Faculty of Animal Health, Bogor Agricultural University \\ ${ }^{5}$ Faculty of Animal Husbandry, Bogor Agricultural University \\ E-mail:nova.dy@gmail.com
}

(received 11-01-2018; revised 18-05-2018; accepted 06-06-2018)

\begin{abstract}
ABSTRAK
Yanthi ND, Said S, Anggraeni A, Damayanti R, Muladno. 2018. Korelasi nilai electric conductivity dengan kualitas susu sapi perah. JITV 23(2): 82-88. DOI: http://dx.doi.org/10.14334/jitv.v23i2.1694

Susu sebagai sumber makanan utama bagi kehidupan mammalia memiliki kandungan elektrolit untuk menggantikan cairan tubuh yang hilang oleh karena aktivitas ataupun proses metabolisme. Konsentrasi total elektrolit dapat diukur berdasarkan nilai konduktivitas yang dihasilkan susu berdasarkan pada komposisi nutrisi yang dikandungnya. Dengan demikian hubungan parameter kualitas susu dengan nilai konduktifitas dapat menjadi tolok ukur untuk kualitas dan nilai jual susu sehingga lebih mudah diaplikasikan di lapangan. Penelitian ini bertujuan menganalisis hubungan antara electric conductivity (EC) dengan nilai kandungan susu sapi. Susu diambil dari 10-30 ekor sapi dari peternakan di Kabupaten Bandung Barat (Lembang), Kabupaten Bandung (Pangalengan), Tasikmalaya, Sumedang, Subang, Sukabumi dan Bogor Provinsi Jawa Barat. Susu ditampung dalam falcon steril $50 \mathrm{ml}$. Probe EC count-meter CT-3031 digunakan untuk mengukur EC sedangkan Probe MilkoScan ${ }^{\mathrm{TM}}{ }_{\mathrm{FT}} 120$ (Foss) digunakan untuk mengukur kualitas susu. Kualitas susu dicerminkan oleh kandungan Protein, Fat, Total Solid (TS), Solid Non Fat (SNF), Lactose, Density, Acidity, dan Freeze Point Deviation (FPD). Hasil penelitian menunjukkan bahwa nilai EC pada susu memberikan pengaruh positif yang sangat nyata $(\mathrm{p}=<0.01)$ terhadap Total Solid (TS), Solid Non Fat (SNF), Lactose dan Freeze Point Deviation (FPD). Selanjutnya nilai EC berpengaruh nyata $(\mathrm{p}=<0.05)$ terhadap nilai density pada susu. Oleh karena itu nilai EC dapat digunakan untuk memprediksi nilai kualitas susu.
\end{abstract}

Kata Kunci: Korelasi, Electric Conductivity, Kualitas Susu

\section{ABSTRACT}

Yanthi ND, Said S, Anggraeni A, Damayanti R, Muladno. 2018. Correlation of electric conductivity values with the dairy milk quality. JITV 23(2): 82-88. DOI: http://dx.doi.org/10.14334/jitv.v23i2.1694

Milk, as the prime source of food for mammals, has an electrolyte to replace the loss of body fluid caused by activity or metabolism process. The total electrolyte concentration can be measured based on conductivity value from the nutritional content. Therefore, the parameter of the quality of milk with conductivity value can be a benchmark for quality and selling value of milk, making it simpler to be implemented in the field. The aim of this research is to analyze the relation between electric conductivity (EC) with the content value of cow milk. The milk was taken from 10-30 cows from a farm in Lembang (district of West Bandung), Pengalengan (district of Bandung), Tasikmalaya, Sumedang, Subang, Sukabumi and Bogor of West Java Province. The milk was put in $50 \mathrm{ml}$ of sterile falcon. The Probe EC count-meter CT-3031 was used to measure EC while the quality of milk was measured by Probe MilkoScan ${ }^{\mathrm{TM}}$ FT 120 (Foss). The milk quality is reflected by protein content, Fat, Total Solid (TS), Solid Non-fat (SNF), Lactose, Density, Acidity and Freeze Point Deviation (FPD). The results of this study show that the EC value in the milk gives a very real positive effect $(\mathrm{p}=<0.01)$ to Total Solid (TS), Solid Non-fat (SNF), Lactose, and Freeze Point Deviation (FPD). The value of EC also significantly affect $(p=<0.05)$ the value of density in milk. Therefore, the value of EC can be used to predict the quality value of milk.

Key Words: Correlation, Electric Conductivity, Milk Quality

\section{INTRODUCTION}

Electric conductivity value is determined by the concentration of anion and cation condition. The electrical conductivity or well known as conductivity is how far a solution may conduct electricity (Irwan \& Afdal 2016), so that the conductivity value of a solution is a measure of total concentration of electrolyte in a solution. Electrolyte solution is a solution consisting of negative and positive ions. In the electrolyte solution, its molecules are dissociated into positive and negative electricity charged particles. These ions then may conduct the electricity. 
Milk is a solution consisting of essential nutritional components to humans needed to improve physiological and biological functions that affect the metabolism and health. These essential components consist of the ideal diet composition that is all chemical components in the form of six main nutrients: water, fat, protein, carbohydrate (including lactose), mineral and vitamin (Chandan 2006; Rezaei et al. 2016). Vegarud et al. (2000) stated that protein, fat, carbohydrate, minerals ( $\mathrm{Na}, \mathrm{K}, \mathrm{Ca}, \mathrm{I}$ etc.) and elements (Fe, $\mathrm{Zn}, \mathrm{Cu}$, ets.) contained in milk. Cow's milk is in a chemical equilibrium with free ion content present in greater quantities than any other form of dairy products. The chemical composition of milk can be influenced by many factors such as breed, environment condition, milking period, and nutrient status of animal (Vegarud et al. 2000; Schanbacher et al. 1998; Korhonen \& Pihlanto-Leppälä 2004; Gobbetti et al. 2007; Kalač et al. 2010; Pereira 2014). Nutrients contained in milk consist of complex compounds that have 100,000 chemical molecules separated from each other (Chandan 2006). These chemical molecules contain free cation and anion elements that can bind to other free ions. The use of EC as a milk analysis has been widely reported. Mammadova \& Keskin (2013) stated that the value of EC was used to detect to detect changes in milk composition associated with an udder condition infected with mastitis is another measure of evidence used in increasing the frequency of milk production. Based on a research result resulted by Norberg et al. (2004b), milk electric conductivity might be used as an indicator of phenotypic and genetic of cow mastitis. Research result of Diaz et al. (2012) also showed that the use of EC to detect the subclinical mastitis as well as its initial condition effectively.

Juozaitiene et al. (2017) said that the electric conductivity might be used to collect information about electric conductivity of milk in the genetic evaluation to improve milk quality. In its application, the measurement using EC is a reading done by capturing the positive and negative ions of a solution. The body requires $\mathrm{Na}^{+}$and $\mathrm{Cl}^{-}$ions in a small, balanced concentration. But it is necessary for the metabolism process in the body. The electrolyte value of a solution may change due to the condition of the body and the environment. It becomes more practical and easy to know by using EC.

\section{MATERIALS AND METHODS}

The dairy cow milk samples analyzed were from 1030 cows in the farms around West Java, consisting of West Bandung District (Lembang), Bandung District (Pangalengan), Tasikmalaya District, Sumedang District, Subang District, Sukabumi District and Bogor District.
Milk is stored in a $50 \mathrm{ml}$ sterile falcon tube then stored in an ice box while on the go in order to maintain milk quality. Milk quality observation was conducted at Animal Health Laboratory, Biotechnology Research Center-Indonesian Institute of Science, Cibinong.

Measurement of electro conductivity of milk was done by using EC count-meter CT-3031. This tool is a fast, reliable and inexpensive method to measure the concentration of solution ions, as well as saving battery because it uses electric w/ATC so also saving battery. The Unit S1 conductivity was Siemen per meter $(\mathrm{s} / \mathrm{m})$. This type of pen conductivity meter is not only lightweight and compact but also waterproof and will provide a $+/-2 \%$ accuracy reading with a range of 0 $19.99 \mathrm{mS}$. The end of "Conductivity/TDS Probe" is immersed in the solution, until submerged. Shake the probe several times to remove air bubbles from internal examination. When the screen reading reached stable, it was the measured conductivity value.

Milk quality measurement was done by using MilkoScan ${ }^{\text {TM }}$ FT 120 (Foss) mechine. This MilkoScan tool can analyze milk quickly and accurately on raw milk, intermediates and the final products. In addition, this tool can also analyze various parameters of milk Fatty Acids, Urea, Fats, Proteins and Lactose in various dairy products. With the completeness of analysis of milk and its dairy products, this tool has a large shape that can't be placed anywhere and expensive, so it can only be placed only in the laboratory. The MilkoScan ${ }^{\mathrm{TM}}$ FT 120 (Foss) probe was dipped in $35-40 \mathrm{ml}$ of milk then did the reading of milk quality value. The data obtained are: protein, fat, total solid, solid nonfat, lactose, density, FPD, and acidity. The obtained data were processed by using SPSS 17 to see correlation between milk quality and EC value.

\section{RESULTS AND DISCUSSION}

\section{The quality of milk}

Essential nutrients in milk in the form of proteins, minerals, and other essential elements are needed as a source of food for growth and body maintenance (Singh et al. 2015; Enb et al. 2009). Milk quality data presented in Table 1 were protein, total solid (TS), Solid Non Fat (SNF), lactose, density, Freeze Point Deviation (FPD), acidity, Electric Conductivity (EC), with comparable milk values based on Indonesian National Standard (SNI). This standard establishes good quality requirements of fresh milk including protein content at a minimum value of $2.8 \%$, a minimum fat content of $3.0 \%$, a minimum SNF of $7.8 \%$, TS of $10.8 \%$, density of $1.027 \mathrm{~g} / \mathrm{ml}$, FPD of $-0.520--0.560$, acidity of $6.0-7.5^{\circ} \mathrm{SH}$ and other requirements in the form of microbiological contamination. Thus if the fresh milk content tested has a value below the 
minimum value of SNI then the fresh milk value is bad. Chemically, the composition of milk consists of fatty emulsions in water containing sugar, mineral salts, and proteins in the form of colloidal suspense, which means that the main components of milk are water, fat, protein (in the form of casein and albumin), lactose (sugar milk) and ash. Besides the water in the milk component, there were TS and SNF components. Each component contained in milk has a concentration that can be affected by several factors, including disease (mastitis), stages in the lactation period, season/climate and food conditions (Bernabucci et al. 2015; Milani 2016). So these factors can change the concentration and condition of milk in quality and quantity.

The result of milk quality analysis obtained from milk samples showed the mean fulfill the quality of SNI. But the minimum and maximum value obtained in the measurement of mastitis milk was still very wide. The minimum protein value of the samples obtained was still very far from the standard of 0.1. Likewise, the maximum value was well above the standard value. For other parameters, the fat concentration, TS, SNF and acidity had a very wide range of values as well. The minimum and maximum value distance of the milk quality parameter content is influenced by many factors. This is reinforced by the statement of Elmoslemany et al. (2010) that basically the quality of milk was influenced by the quality of feed offered. It was also influenced by management. The comparison between concentrate and forage feed can also affect the value of the concentration of milk quality. In addition to feed, livestock and climate conditions can also determine the concentration of milk quality (Milani et al. 2015;
Gellrich et al. 2015). Healthy cows will have better milk quality and qualify for SNI.

\section{The correlation between EC and milk quality}

Table 2 shows the relationship between EC and the composition of milk content which shows the relationship of each parameter with EC. In addition, each parameter also has a close relationship with each other. Proteins had a very real sequence of TS, SNF, lactose, FPD, and Acidity. Then fat had a very real relationship to the TS and density and had a real relationship to the EFF. TS had a very real relationship to the other three variables in addition to protein and Fat were SNF, density, and FPD. Besides, TS also had a very real sequence with EC. SNF parameters had a similar relationship to TS plus a very strong relationship to lactose. Lactose had a very real relationship to the four parameters of protein, SNF, density, and EC. Density had a very real relationship with five parameters of fat, TS, SNF, lactose, and FPD, also to EC. The FPD was a parameter that had a very significant correlation between the five parameters of protein, fat, TS, SNF and density and the apparent relationship of acidity besides FPD also had a very real relationship to EC. The acidity parameter had a very real relationship to the protein and the data relationship to the EFF. Of the eight milk quality parameters of protein, fat, TS, SNF, lactose, density, FPD and acidity, the most obvious correlation to EC were TS, SNF, lactose, and FPD and a significant relationship with density.

Table 1. Milk quality of dairy milk in West Java

\begin{tabular}{|c|c|c|c|c|}
\hline Parameter & Minimal & Maximal & Mean & SNI \\
\hline Protein & 0.1 & 6.95 & $2.81 \pm 1.060$ & 2.8 \\
\hline Fat & 0.31 & 11.19 & $3.05 \pm 1.944$ & 3.0 \\
\hline $\mathrm{TS}$ & 7.8 & 19.17 & $11.21 \pm 2.202$ & 10.8 \\
\hline SNF & 1 & 10.32 & $7.53 \pm 2.061$ & 7.8 \\
\hline Lactose & 0.34 & 9.34 & $5.03 \pm 1.857$ & - \\
\hline Density & 1015 & 1037 & $1029.45 \pm 4.692$ & 1.027 \\
\hline FPD & 0.311 & 0.648 & $0.50 \pm 0.59$ & $-0.520-0.560$ \\
\hline Acidity & 3.43 & 14.43 & $6.70 \pm 1.663$ & $6.0-7.5$ \\
\hline $\mathrm{EC}$ & 1.33 & 9.47 & $4.59 \pm 1.278$ & - \\
\hline
\end{tabular}


Table 2. Pearson correlation of milk quality and electric conductivity value

\begin{tabular}{|c|c|c|c|c|c|c|c|c|c|c|}
\hline & & Protein & Fat & TS & SNF & Lactose & Density & FPD & Acidity & $\mathrm{EC}$ \\
\hline \multirow[t]{2}{*}{ Protein } & Pearson Correlation & 1 & -.035 & $.421^{* *}$ & $.503^{* *}$ & $-.512^{* *}$ & -.143 & $.274^{* *}$ & $.274^{* *}$ & -.142 \\
\hline & Sig. (2-tailed) & & .689 & .000 & .000 & .000 & .105 & .002 & .002 & .106 \\
\hline \multirow[t]{2}{*}{ Fat } & Pearson Correlation & -.035 & 1 & $.834^{* *}$ & -.054 & .003 & $-.524^{* *}$ & $.179^{*}$ & -.017 & -.125 \\
\hline & Sig. (2-tailed) & .689 & & .000 & .545 & .976 & .000 & .042 & .846 & .156 \\
\hline \multirow[t]{2}{*}{ TS } & Pearson Correlation & $.421^{* *}$ & $.834^{* *}$ & 1 & $.328^{* *}$ & -.144 & $-.273^{* *}$ & $.538^{* *}$ & .061 & $-.312^{* *}$ \\
\hline & Sig. (2-tailed) & .000 & .000 & & .000 & .101 & .002 & .000 & .489 & .000 \\
\hline \multirow[t]{2}{*}{ SNF } & Pearson Correlation & $.503^{* *}$ & -.054 & $.328^{* *}$ & 1 & $-.706^{* *}$ & $.340^{* *}$ & $.517^{* *}$ & .103 & $-.525^{* *}$ \\
\hline & Sig. (2-tailed) & .000 & .545 & .000 & & .000 & .000 & .000 & .245 & .000 \\
\hline \multirow[t]{2}{*}{ Lactose } & Pearson Correlation & $-.512^{* *}$ & .003 & -.144 & $-.706^{* *}$ & 1 & $.308^{* *}$ & .148 & -.077 & $.261^{* * *}$ \\
\hline & Sig. (2-tailed) & .000 & .976 & .101 & .000 & & .000 & .092 & .386 & .003 \\
\hline \multirow[t]{2}{*}{ Density } & Pearson Correlation & -.143 & $-.524^{* *}$ & $-.273^{* *}$ & $.340^{* *}$ & $.308^{* * *}$ & 1 & $.575^{* *}$ & .053 & $-.219^{*}$ \\
\hline & Sig. (2-tailed) & .105 & .000 & .002 & .000 & .000 & & .000 & .549 & .012 \\
\hline \multirow[t]{2}{*}{ FPD } & Pearson Correlation & $.274^{* *}$ & $.179^{*}$ & $.538^{* *}$ & $.517^{* *}$ & .148 & $.575^{* *}$ & 1 & $.201^{*}$ & $-.376^{* *}$ \\
\hline & Sig. (2-tailed) & .002 & .042 & .000 & .000 & .092 & .000 & & .022 & .000 \\
\hline \multirow[t]{2}{*}{ Acidity } & Pearson Correlation & $.274^{* *}$ & -.017 & .061 & .103 & -.077 & .053 & $.201^{*}$ & 1 & -.058 \\
\hline & Sig. (2-tailed) & .002 & .846 & .489 & .245 & .386 & .549 & .022 & & .510 \\
\hline \multirow[t]{2}{*}{$\mathrm{EC}$} & Pearson Correlation & -.142 & -.125 & $-.312^{* *}$ & $-.525^{* *}$ & $.261^{* *}$ & $-.219^{*}$ & $-.376^{* *}$ & -.058 & 1 \\
\hline & Sig. (2-tailed) & .106 & .156 & .000 & .000 & .003 & .012 & .000 & .510 & \\
\hline
\end{tabular}


The increasing of EC value of milk may also indicate substantial variation in the absence of mastitis this may be due to many factors such as lactation stages, cow age, milking intervals and cow-milk conditions (Biggadike et al. 2000). In addition, according to Kaşikçi et al. (2012), EC value increase is a change that occurs to the mineral content in milk. Factors such as milk temperature, $\mathrm{pH}$ and fat concentration in milk also have an effect on EC measurement (Qayyum et al. 2016)

This research result is the EC value had a very significant positive effect $(\mathrm{P} \leq 0.01)$ on the four parameters of milk composition i.e., TS, SNF, Lactose and FPD. Total Solid was a dissolved solid and/or total suspended solids. This parameter had a very large influence on the milk content. TS is a component consisting of proteins, fats, carbohydrates, lactose, minerals, and vitamins. Under normal conditions the milk produced in a healthy udder will contain a balanced and healthy chemical composition of milk, making it feasible for consumption. The balance of the chemical composition of milk is obtained from a balanced diet between forage and concentrate (Kholif et al. 2014; Villeneuve et al. 2013).

Protein in milk consists of $80 \%$ casein which is resistant to low $\mathrm{pH}$ and $20 \%$ whey (Malacarne et al. 2002; Pegoretti et al 2015). Chemically, a protein is a polymer made of 20 amino acid proteinogenic. Amino acids contained in casein consist of histidine, methionine, phenylalanine, and other non-essential amino acids, arginine, glutamine, proline, serine and tyrosine. With the acid-resistant properties of casein, the amino acids constituent are amino acids that are soluble in an acid-containing solvent. Amino acid content in whey consists of leucine, isoleucine, and valine (Boisen et al. 2000). Mohan et al. (2014) stated that whey protein in cow's milk has a negative charge at $\mathrm{pH} 6.6$ (normal milk pH), so whey is a dissolved protein fraction. This is reinforced by the statement of Pereira (2014) that the fraction of proteins can be divided into two i.e., soluble and insoluble proteins. The soluble protein is represented by whey. Thus the concentration of milk protein will greatly affect the value of electrical conductivity. Some of these amino acids are composed of amino acids that have different polarities with each other. This level of polarity will determine the value of the ions to be produced, so this will also affect the value of EC. According to $\mathrm{Wu}$ (2013), amino acids have a very extraordinary role in life ranging from metabolic processes, growing physiology and immunity.

Milk fat is composed of triacylglycerol and some other fats. Fat is one tool in assessing the quality of milk. Fat has a low solubility level of normal diluted, but it can dissolve in acid solvents. Vitamins contained in milk are vitamins $\mathrm{A}, \mathrm{D}, \mathrm{B}, \mathrm{K}, \mathrm{C}$, and $\mathrm{E}$. These vitamins are highly dependent on feed intake and sun exposure is obtained (Gorewit 2016). Mineral milk content is composed of monovalent ions namely $\mathrm{Na}, \mathrm{K}$, and chloride $(\mathrm{Cl})$. These ions are the most common mineral type of ion suspension present in a free state in milk. This salt ion collectively contributes for more than $25 \%$ of the total osmolarity of cow's milk. There are also divalent ions: calcium $(\mathrm{Ca})$, magnesium $(\mathrm{Mg})$, citrate, phosphate $(\mathrm{P})$ and sulfate and some other elements of copper, iron, silicon, zinc, and iodine. These mineral ions have a great influence during lactation in physiological conditions to open and close the intersections between epithelial cells in the milk glands ( $\mathrm{Li}$ 2016). In addition, minerals also play an important role in the stability of milk proteins (Mohan et al. 2014). This difference in composition, fat, protein, vitamins and minerals will affect the value of EC. Because there are components of these nutrients can conduct electricity.

SNF is a milk component consisting of nonfat dry material. The SNF content consisting of protein, lactose, and mineral (Chandan 2006). Concentrations of proteins, lactose, vitamins, and minerals will greatly affect the value of EC. According to Norberg et al. (2004a), the infected udder of bacteria will increase $\mathrm{Na}^{+}$ and $\mathrm{Cl}^{-}$concentration in milk which produce high conductivity. High values of $\mathrm{Na}^{+}$and $\mathrm{Cl}^{-}$cause the value of milk content will decrease.

The FPD is a measure of the milk condition to the level of milk freezing. The freezing point in milk is affected by the dissolved components in milk, especially the components of amino acids (proteins), lactose, vitamins and minerals. This component is very influential on dairy products both in yogurt, cheese and others. According to McCarthy \& Singh (2009), the rate of decrease in freezing point will be proportional to the molality of a solution. The content of milk consisting of lactose, chloride salt and other water-soluble ingredients (such as calcium, potassium, magnesium, lactate, phosphate, citrate, etc.) each contribute to a decrease in freezing points of about 55, 25, and $20 \%$. The amount of ions in the solution is also affected by the dissolved solids in it. The greater the amount of dissolved solids in solution, the more likely the number of ions in the solution will increase, so that the electrical conductivity value will also increase (Mohan et al. 2014).

In addition, EC also has a very real effect on lactose. Lactose is the major carbohydrate in cow's milk is a disaccharide consisting of one glucose residue and one galactose residue (Mohan et al. 2014). The concentration of lactose in milk is about $4.8-5.2 \%$ of the total weight of cow's milk volume (O'Mahony \& Fox 2014). In solution, lactose undergoes mutarotation between $\alpha$ and $\beta$ forms, involving the interchanging of $\mathrm{OH}$ and $\mathrm{H}$ groups in the reducing group. Mutarotation of lactose depends on temperature and $\mathrm{pH}$ (Mohan et al. 
2014). The low concentration of lactose values in milk can increase the value of EC. This is in accordance with the statement of Fahmid et al. (2016). Mastitis conditions affect lactose levels where the condition of the erythrocyte. Inflammation is caused by bacterial mastitis and can increase the concentration of $\mathrm{Na}^{+}$and $\mathrm{Cl}^{-}$ions and decrease the levels of $\mathrm{K}^{+}$and lactose ions so that the EC value will increase. Even though electrolyte dissolved sugar does not provide an increase in the value of positive and negative ions, but with the destruction of cell tissues in the infected udder as a milk making "factory" in the mastitis, udders can increase $\mathrm{Na}^{+}$and $\mathrm{Cl}^{-}$. Varman \& Sutherland (2001) has explained that lactose makes a major contribution to the milk's colligative properties, such as the osmotic pressure, the depression freezing point, and the boiling point.

Another effect that gives significant results on cow milk content so that it can also affect the value of EC is the value of density. The density value had a significant correlation to EC $(\mathrm{P} \leq 0.05)$. The density value describes the mass weight of a substance or solution. Density of milk consists of milk-forming mass such as protein, fat, lactose and minerals, so the density value will affect the EC value because milk mass formers consist of milk forming components. Variations in electrical conductivity caused by changes in $\mathrm{Na}, \mathrm{K}$ and $\mathrm{Cl}$ milk is highly likely due to several factors such as nutrition, age, type, parity, milking intervals and milk composition other than mastitis (Norberg 2005).

\section{CONCLUSION}

The overall milk analyzed showed mean value that still remained on the value of milk nutrient quality based on the SNI. Analysis value using EC had correlation to milk quality. The components of milk that had significant effect $(\mathrm{P}<0.01)$ on EC value were Total Solid, Solid Non Fat, Lactose, FPD. The component that had significant effect $(\mathrm{P}<0.05)$ to $\mathrm{EC}$ value was Density. EC had a close correlation with milk quality, and EC can be used to predict the value of milk quality.

\section{ACKNOWLEDGEMENT}

The research was funded by the National Synergy Insertion Grant of 2016 from the Ministry of Technology and Higher Education Research. No .: 290 / SP2H / LT / DRPM / III / 2016.

\section{REFERENCES}

Bernabucci U, Basiricò L, Morera P, Dipasquale D, Vitali A, Piccioli-Cappelli F, Calamari L. 2015. Effect of summer season on milk protein fractions in Holstein cows. J Dairy Sci. 98:1815-1827.

Biggadike H, Ohnstad I, Hillerton E. 2000. A practical evaluation of milk conductivity measurements. Proceeding of British Mastitis Conference Shepton Mallet, Institute for Animal Health/Milk Development Council. p. 56-61.

Boisen S, Hvelplund T, Weisbjerg MR. 2000. Ideal amino acid profiles as a basis for feed protein evaluation. Livest Prod Sci. 64:239-251.

Chandan RC. 2006. Manufacturing yogurt and fermented milks. New Jersey (USA): Blackwell Publishing.

Díaz JR, Romero G, Muelas R, Alejandro M, Peris JC. 2012. Effect of intramammary infection on milk electrical conductivity in Murciano-Granadina goats. J Dairy Sci. 95:718-726

Elmoslemanya AM, Keefea GP, Dohooa IR, Wichtela JJ, Stryhna H, Dingwelle RT. 2010. The association between bulk tank milk analysis for raw milk quality and on-farm management practices. Prev Vet Medic. 95:32-40.

Enb A, Abou-Donia MA, Abd-Rabou NS, Abou-Arab AAK, El-Senaity MH. 2009. Chemical composition of raw milk and heavy metals bahavior during processing of milk products. Global Vet. 3:268-275.

Fahmid S, Hassan E, Naeem H, Barrech S, Lodhi S, Latif S. 2016. Determination of mastitis by measuring milk electrical conductivity. Int J Adv Res Biol Sci. 3:1-4.

Gellrich K, Sigl T, Meyer HHD, Wiedemann S. 2015. Cortisol levels in skimmed milk during the first 22 weeks of lactation and response to short-term metabolic stress and lameness in dairy cows. J Anim Sci Biotechnol. 6:31.

Gobbetti M, Minervini F, Rizzello CG. 2007. Bioactive peptides in dairy products. In: Hui $\mathrm{YH}$, editor. Handbook of food products manufacturing. New Jersey (USA): John Wiley \& Sons. p. 489-517.

Gorewit RC. 2016. Lactation biology and methods of increasing efficiency. Designing foods: Animal product options in the marketplace. Washington DC (USA): National Academic Press. p. 208-223.

Irwan F, Afdal. 2016. Analisis hubungan konduktivitas listrik dengan Total Dissolved Solid (TDS) dan temperatur pada beberapa jenis air. J Fisika Unand. 5:58-93.

Juozaitienė V, Anskienè L, Čereškienè E, Juozaitis A, Žymantienè J, Žilaitis V, Bobinienė R. 2017. Electrical conductivity of milk in different milking phases and relationship with subclinical mastitis and mastitis pathogens of cows. J Anim Plant Sci. 27:1829-1835.

Kalač P, Samková E. 2010. The effects of feeding various forages on fatty acid composition of bovine milk fat: A review. Czech J Anim Sci. 55:521-537.

Kaşikçi G, Çetin Ö, Bingöl EB, Gündüz MC. 2012. Relations between electrical conductivity, somatic cell count, California mastitis test and some quality parameters in 
the diagnosis of subclinical mastitis in dairy cows. Turk J Vet Anim Sci. 36:49-55.

Korhonen H, Pihlanto-Leppala A. 2004. Milk-derived bioactive peptides: formation and prospects for health promotion. In: Shortt C, O'Brien J, editors. Handbook of Functional Dairy Products. Florida (USA): CRC Press. p. 109-124.

Kholif AE, Khattab HM, El-Shewy AA, Salem AZM, Kholif AM, El-Sayed MM, Gado HM, Mariezcurrena MD. 2014. Nutrient digestibility, ruminal fermentation activities, serum parameters and milk production and composition of lactating goats fed diets containing rice straw treated with Pleurotus ostreatus. Asian-Australas J Anim Sci. 27:357-364.

Li X. 2016. Electrical conductivity as an indicator of milk spoilage for use in biosensor technology (Thesis). [Dunedin (New Zealand)]: University of Otago.

Malacarne M, Martuzzi F, Summer A, Mariani P. 2002. Protein and fat composition of mare's milk: Some nutritional remarks with reference to human and cow's milk. Int Dairy J. 12:869-877.

Mammadova N, Keskin E. 2013. Research article: Application of the support vector machine to predict subclinical mastitis in dairy cattle. The Scientific World J. 2013, Article ID 603897, 9 pages http://dx.doi.org/10.1155/2013/603897.

McCarthy OJ, Singh H. 2009. Physico-chemical properties of milk. In: McSweeney P, Fox P, editors. Advanced Dairy Chemistry. New York (USA): Springer.

Milani MRM, Hense A, Rahmani E, Ploeger A. 2015. A pilot investigation of the relationship between climate variability and milk compounds under the bootstrap technique. Foods. 3:420-439.

Milani MRM. 2016. The effect of climate variability on main components of cow milk in Iran (Dissertation). [Kassel (Germany)]: University of Kassel.

Mohan MS, Hopkinson J, Hart F. 2014. Milk and ice cream processing. food processing: Principles and applications. 2nd ed. New Jersey (USA): John Wiley \& Sons.

Norberg E, Hogeveen H, Korsgaard IR, Friggens NC, Sloth KHMN, Løvendahl P. 2004a. Electrical conductivity of milk: Ability to predict mastitis status. J Dairy Sci. 87:1099-1107.

Norberg E, Rogers GW, Goodling RC, Cooper JB, Madsen P. 2004b. Genetic parameters for test day electrical conductivity of milk for first lactation cows from random regression models. J Dairy Sci. 87:1917-1924.

Norberg E. 2005. Electrical conductivity of milk as a phenotypic and genetic indicator of bovine mastitis: a review. Livest Prod Sci. 96:129-139.

O'Mahony JA, Fox PF. 2014. Milk: An overview. In: Boland M, Singh H, Thompson A, editors. Milk proteins: From expression to food. 2nd ed. New York (USA): Academic Press, Elsevier New York.

Pegoretti C, Antunes AEC, Manchado-Gobatto FdB, Capitani CD. 2015. Milk: An alternative beverage for hydration?. Food Nutr Sci. 6:547-554.

Pereira PC. 2014. Milk nutritional composition and its role in human health. Nutrition. 30:619-627.

Qayyum A, Ali-Khan J, Hussain R, Avais M, Ahmad N, Sarwar-Khan M. 2016. Investigation of milk and blood serum biochemical profile as an indicator of sub-clinical mastitis in Cholistani cattle. Pak Vet J. 36:275-279.

Rezaei R, Wu Z, Hou Y, Bazer FW, Wu G. 2016. Amino acids and mammary gland development: nutritional implications for milk production and neonatal growth. $\mathrm{J}$ Anim Sci Biotechnol. 7:20.

Schanbacher FL, Talhouk RS, Murray FA, Gherman LI, Willet LB. 1998. Milk-born bioactive peptides. Int Dairy J. 8:393-403.

Singh M, Yadav P, Garg VK, Sharma A, Singh B, Sharma H. 2015. Quantification of minerals and trace elements in raw caprine milk using flame atomic absorption spectrophotometry and flame photometry. J Food Sci Technol. 52:5299-5304.

Varman HA, Sutherland JP. 2001. Milk and milk products: technology, chemistry and microbiology. Frederick (USA): ASPEN Publishers Inc.

Vegarud GE, Langsrud T, Svenning C. 2000. Mineral-binding milk proteins and peptides; occurrence, biochemical and technological characteristics. Br J Nutr. 84:91-98.

Villeneuve MP, Lebeuf Y, Gervais R, Tremblay GF, Vuillemard JC, Fortin J, Chouinard PY. 2013. Milk volatile organic compounds and fatty acid profile in cows feed timothy as hay, pasture or silage. J Dairy Sci. 96:7181-7194.

Wu G. 2013. Functional amino acids in nutrition and health. Amino Acids. 45:407-411. 